DE DE GRUYTER

OPEN

\title{
LEAD POLLUTED HOTSPOT: ENVIRONMENTAL IMPLICATION OF UNPLANNED INDUSTRIAL DEVELOPMENT
}

\author{
Sharmin Yousuf Rikta ${ }^{1}$, Md. Shiblur Rahaman ${ }^{2}$, Md. Mostafizur \\ Rahman ${ }^{1}$, Shafi Mohammad Tareq ${ }^{3}$
}

Key words: Bangladesh; Environment; Pollution; Hydrogeochemistry; Lead (Pb).

\begin{abstract}
In Rayer Bazaar, different industries like tannery, plastic, textile, battery recycling industry etc. are increasing rapidly without considering the environmental issues and deterioration. Since chromium $(\mathrm{Cr})$ pollution of this area has been widely investigated due to the presence of tannery industries, this study was focused on examining other environmental factors. Field visits and analytical results of semi-quantitative and quantitative analysis as well as three dimensional excitation emission matrix spectroscopy (3DEEM) of water, soil and vegetative tissues indicated that, the area is highly polluted in term of different environmental parameters and metal content. The extremely high lead $(\mathrm{Pb})$ content of the soil $(1171.7 \mathrm{mg} / \mathrm{kg}$ in summer, $2157.1 \mathrm{mg} / \mathrm{kg}$ in winter) and blackish materials of vegetative tissues $(6585.6 \mathrm{mg} / \mathrm{kg}$ in summer, $1974.1 \mathrm{mg} / \mathrm{kg}$ in winter) indicates excessive lead deposition of this area that makes it a lead polluted hotspot. One of the possible sources of the extremely high lead concentration is adjacent battery recycling industry and/or other industries surrounding this area. So it is urgent to take necessary steps to find out immediate options for possible mitigation.
\end{abstract}

\section{Introduction}

The dread of environmental degradation has touched almost all conscious people all over the world. The problem has taken an acute form in developing countries like Bangladesh [1].The country faces a demographic challenge that drags her into a state of sprawling urbanization, expansive industrialization and

\footnotetext{
${ }^{1}$ Department of Environmental Sciences, Jahangirnagar University, Savar, Dhaka- 1342, Bangladesh.rikta.env@gmail.com

2 Department of Environmental Science and Disaster Management, Noakhali Science and Technology University, Noakhali-3814, Bangladesh.

${ }^{3}$ School of Biosciences, The University of Nottingham, Jalan Broga, Semenyih, Selangor Darul Ehsan, Malaysia.
} 
escalating consumption. The result is a galloping increase in waste generation and resultant disruption of environment by fouling of air, water and soil by incessant flow of wastes [2]. The present environmental condition of Dhaka city is not at all equilibrium. Soil, water and air pollution are threatening public health, ecosystems and economy. Intense urbanization, large scale industrialization and unprecedented population growth in the last few decades have been responsible for lowering environmental quality [3]. In Bangladesh more than 1200 industrial sites were identified by the Department of Environment, Government of Bangladesh in 1997 as causing significant pollution. Industrial activities, discharge untreated or poorly treated industrial wastewater, effluent and even sludge into the surrounding environment that can decrease soil quality by increasing concentrations of pollutants such as heavy metals, resulting in adverse effects on macrophytes, soil fauna and human health $[4,5]$.

Water pollution stems from many pollutants and sources including, but not limited to, toxic chemicals from industrial activities, solid waste from urban areas with inadequate garbage collection and nutrient pollution from both point sources and non-point sources. Good water quality resources depends on a large number of physicochemical parameters and the magnitude and source of any pollution load; and to assess that monitoring of these parameters is essential [6]. The objectives of this study were to investigate the environmental implication of unplanned industrial development of the study area and analysis of water and soil quality as well as metal content in vegetative tissues.

\section{Materials and Methods}

\subsection{Study Area}

The study was conducted beside Matador Ball pen industry $\left(23^{\circ} 43^{\prime} 24.7^{\prime \prime} \mathrm{N}\right.$ \& $90^{\circ} 22^{\prime} 09.7^{\prime \prime}$ E) which is located at Rahmat Ali road, West Rosulpur, Rayer bazaar, Dhaka, the capital of Bangladesh. Industry site is accessible by road from Gabtoli bus stand and the distance is few $\mathrm{km}$. The area is basically semi-urban in nature with a good number of inhabitants and many industries in the surrounding areas.

\subsection{Sample Collection}

Six water samples were collected from the small wetland beside the matador Ball pen Industry. This wetland is not connected with any running stream or river but it is the storage of the runoff of surroundings. Water samples were collected from 15-30 cm below the water surface and at distances of 1-2 meter from the bank of the wetland in labeled sample bottles that were washed with concentrated $\mathrm{HNO}_{3}$ and rinsed repeatedly with distilled water. Six soil samples 
were collected from the bottom sediment of the wetland and the leaves were collected from garden of Matador Ball pen industry. The sampling bottles were transferred to the laboratory by using ice box that controlled the temperature below $4^{\circ} \mathrm{C}$ as early as possible. All the samples were collected in two seasons, winter (December) and summer (May).

\subsection{Experimental/Analysis}

Hydrogen ion concentration (pH), Dissolve Oxygen (DO), Total Dissolve Solid (TDS) and Redox potential (Rh) of water and soil samples were determined by using a calibrated digital multi-meter $(\mathrm{HACH}, 51910)$. Electrical conductivity (EC) was measured at $25{ }^{\circ} \mathrm{C}$ in $\mu \mathrm{S} / \mathrm{cm}$, using an electric conductivity meter (HANNA, HI 8033). Turbidity of water was measured by using turbidity meter (HANNA, HI 93703). Biochemical Oxygen Demand (BOD) was done by 5-days incubation, $20^{\circ} \mathrm{C}$ method [7]. Qualitative functional characteristics of surface waters dissolved organic matter and isolated blackish material from vegetation leaves were determined by using three dimensional excitation emission matrix fluorescence spectrophotometer (Hitachi F-4600). Lead and other chemical species content of the water and soil samples as well as isolated blackish material from vegetation leaves were first identified by semiquantitative chemical analysis and finally determined using Atomic Absorption Spectrometer (Shimadzu AA 7000).

\section{Results and Discussion}

\subsection{Hydrogeochemistry of the study area}

Table1 shows the analytical results of chemical analysis of the water samples collected from study area.

Table 1: Physicochemical parameters of water samples in summer and winter

\begin{tabular}{ccccccccc}
\hline \multirow{2}{*}{ Season } & $\begin{array}{c}\text { Sample } \\
\text { ID }\end{array}$ & $\begin{array}{c}\text { DO } \\
(\mathbf{m g} / \mathbf{L})\end{array}$ & $\mathbf{p H}$ & $\begin{array}{c}\text { EC } \\
(\boldsymbol{\mu} \mathbf{S} / \mathbf{c m})\end{array}$ & $\begin{array}{c}\text { TDS } \\
(\mathbf{m g} / \mathbf{L})\end{array}$ & $\begin{array}{c}\text { Turbidity } \\
(\mathbf{F T U})\end{array}$ & $\begin{array}{c}\text { Rh } \\
(\mathbf{m V})\end{array}$ & $\begin{array}{c}\text { BOD } \\
(\mathbf{m g} / \mathbf{L})\end{array}$ \\
\hline \multirow{3}{*}{ Summer } & $\mathrm{W}-1$ & 1.09 & 7.39 & 1005 & 496 & 30.24 & -20.4 & 29.05 \\
& $\mathrm{~W}-2$ & 1.19 & 7.45 & 1095 & 507 & 37.06 & -25.7 & 25.41 \\
& $\mathrm{~W}-3$ & 1.05 & 7.44 & 1109 & 498 & 35.67 & -16.8 & 22.76 \\
& $\mathrm{~W}-1$ & 2.53 & 7.04 & 1043 & 467 & 38 & -18.35 & 18.82 \\
Winter & $\mathrm{W}-2$ & 2.09 & 7.13 & 1102 & 463 & 32 & -22.32 & 23.04 \\
& $\mathrm{~W}-3$ & 2.15 & 7.09 & 1057 & 471 & 37 & -19.13 & 21.55 \\
Mean & & 1.68 & 7.25 & 1068.5 & 483.66 & 34.99 & -20.45 & 23.43 \\
STDEV & & 0.65 & 0.19 & 40.69 & 18.80 & 3.14 & 3.18 & 3.48 \\
Variance & & 0.42 & 0.04 & 1655.9 & 353.47 & 9.86 & 10.11 & 12.17 \\
\hline
\end{tabular}




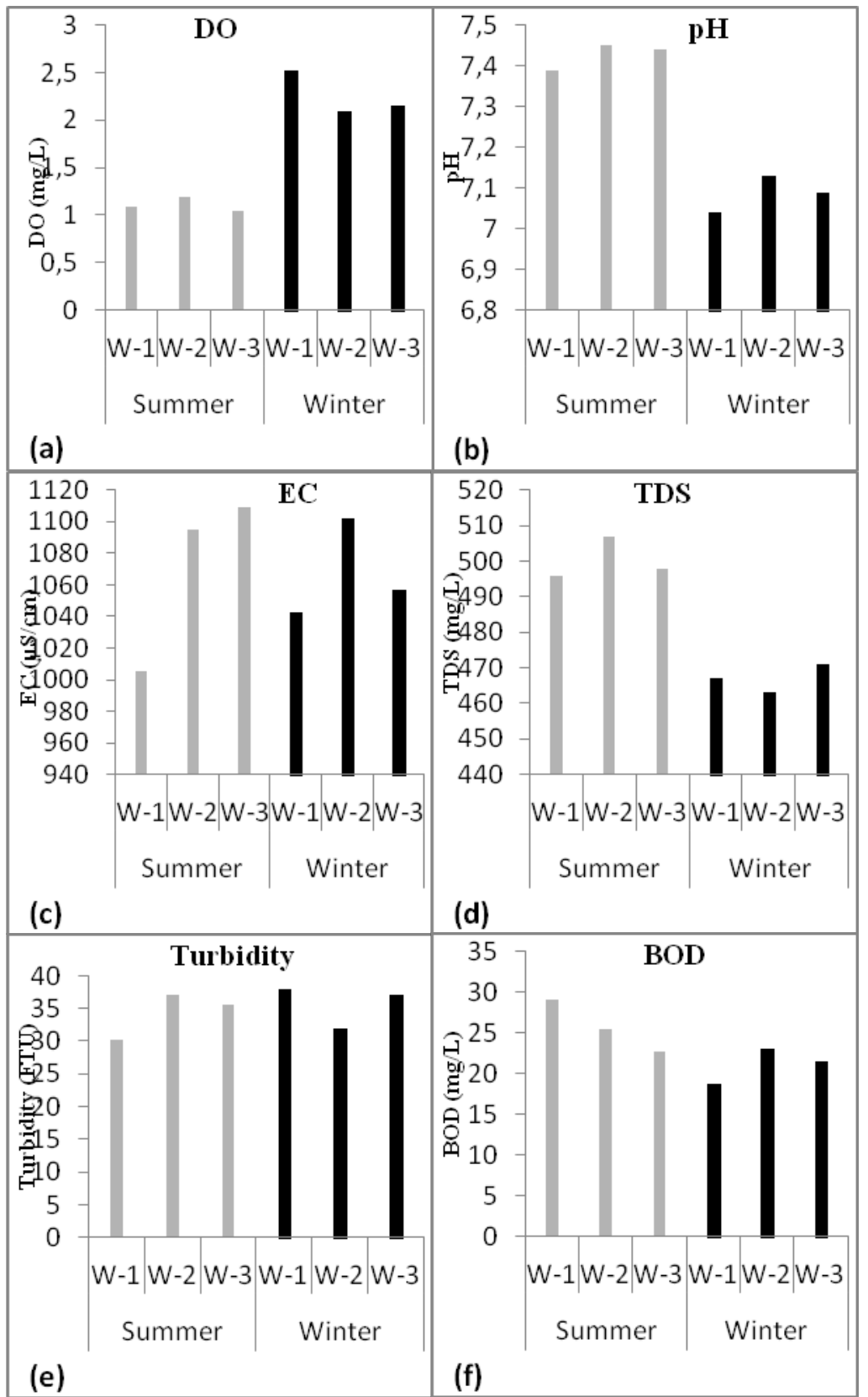

Fig 1: Physicochemical parameters of water samples of the study area. 
Analytical data indicated that most of the important environmental parameters of the samples exceeded the maximum permissible limit for Bangladesh standard. DO of the surface water samples ranges from $1.05 \mathrm{mg} / \mathrm{L}$ in summer to $2.53 \mathrm{mg} / \mathrm{L}$ in winter (Figure 1a) respectively, where $6 \mathrm{mg} / \mathrm{L}$ is the Bangladesh standard for surface water body $[8,9]$. Relatively higher DO value in winter and low value in summer season. Winter maxima might be due to the clear zone, fall in temperature, increased in the solubility of oxygen, slightly more photosynthetic activities and high aeration rate whereas summer minima might be due to the increased organic matter from surface runoff. The main reason DO levels might fall is the presence of organic waste. The average value of DO levels indicates the average quality of river water [10].

Figure $1 \mathrm{~b}$ shows that, the $\mathrm{pH}$ values of water samples were within the $\mathrm{pH}$ range assigned by world health organization (WHO) as the standard for drinking water which ranges from 6.5-8.5 [11]. Fluctuations in $\mathrm{pH}$ values during different season of the year were attributed to factors like removal of $\mathrm{CO}_{2}$ by photosynthesis through bicarbonate degradation, dilution of river with fresh water, reduction in salinity and temperature and decomposition of organic matter [12]. Conductivity of water varies directly with the temperature and is proportional to its dissolved mineral matter content [13]. EC values (Figure 1c) are beyond the Bangladesh standard limit $(750 \mu \mathrm{S} / \mathrm{cm})$, whereas TDS value (Figure1d) was within the standard limit (1000mg/L) [9].

Table 2: Physicochemical properties of soil samples of the study area.

\begin{tabular}{ccccccc}
\hline Season & Sample ID & Color & Odor & pH & EC $(\boldsymbol{\mu S} / \mathbf{c m})$ & Rh $(\mathbf{m V})$ \\
\hline \multirow{3}{*}{ Summer } & S-1 & Blackish & Pungent & 8.18 & 426 & -63.9 \\
& S-2 & Blackish & Pungent & 8.07 & 458 & -68.7 \\
& S-3 & Blackish & Pungent & 8.05 & 432 & -65.8 \\
\multirow{4}{*}{ Winter } & S-1 & Blackish & Pungent & 7.8 & 461 & -58.13 \\
& S-2 & Blackish & Pungent & 7.7 & 433 & -57.98 \\
Mean & S-3 & Blackish & Pungent & 7.4 & 398 & -66.75 \\
STDEV & & & & 7.86 & 434.66 & -63.54 \\
Variance & & & & 0.29 & 23.09 & 4.52 \\
\hline
\end{tabular}

Turbidity and suspended solids are important variables relative to transport and bioavailability of contaminants. Turbidity value also exceeded the Bangladesh standard limit (10FTU) (Figure 1e). Figure 1f shows that, BOD values vary from $18.82 \mathrm{mg} / \mathrm{L}$ to $29.05 \mathrm{mg} / \mathrm{L}$ in winter to summer where the permissible limit of BOD for drinking water is $0.2 \mathrm{mg} / \mathrm{L}$, recreation $3 \mathrm{mg} / \mathrm{L}$, fish $6 \mathrm{mg} / \mathrm{L}$ and $10 \mathrm{mg} / \mathrm{L}$ for irrigation [9]. So the BOD values were not suitable for fish culture, recreation and drinking purposes. This also indicated high level of 
organic pollution. When BOD levels are high, dissolved oxygen (DO) levels decrease because the oxygen that is available in the water is being consumed by the bacteria [14].

Table 2 shows the analytical results of the physicochemical analysis data of the soil samples collected from study area. Soil color, odor, $\mathrm{pH}, \mathrm{EC}$ and $\mathrm{Rh}$ were measured to know the soil status of the study area. All the soil samples were blackish in color and pungent in odor indicating lower soil quality.

Soil $\mathrm{pH}$ is very important to understand the nutrients status of the soil. $\mathrm{pH}$ 67 is optimum for adequate availability of nutrients [15]. At the study area soil the minimum $\mathrm{pH}$ value was 7.4 in winter and the maximum 8.18 in summer. EC $(398-461 \mu \mathrm{S} / \mathrm{cm})$ and $\mathrm{Rh}$ values were also influenced by the industrial wastes and effluents.

\subsection{Possible Organic Contaminants}

Surface water and blackish materials collected from plant leafs of the garden of Matador industry were also characterized by three dimensional excitation emission matrix spectroscopy (3DEEM) with two characteristic excitation and emission wavelengths, one, major peak and another one as a minor peak (Figure 2).

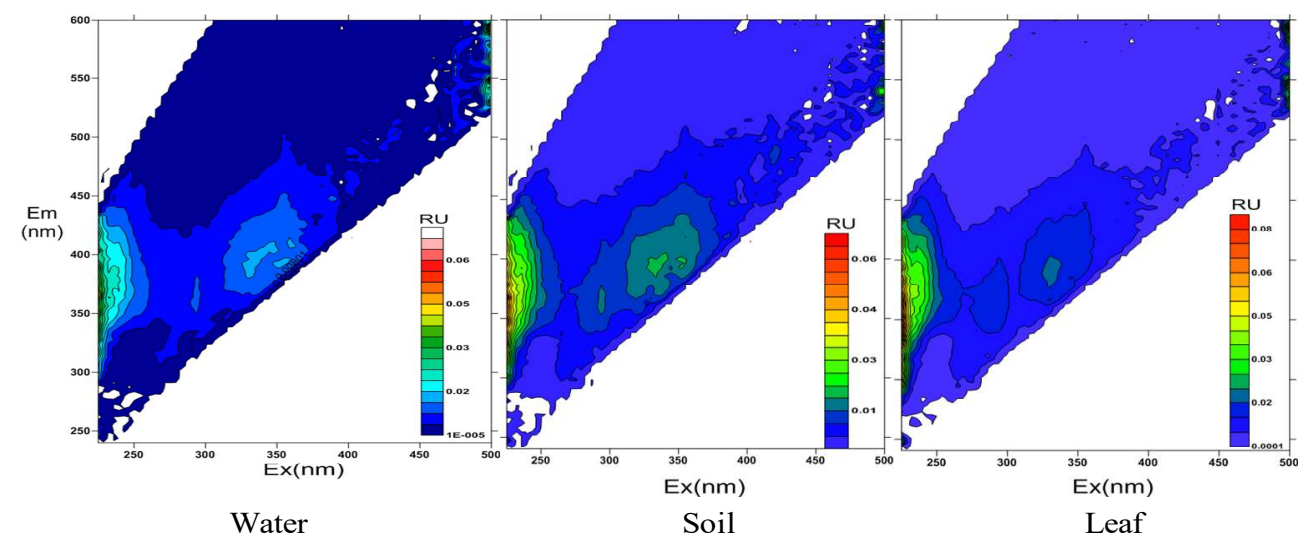

Figure 2: EEM plots of surface water, soil and blackish materials of plant leaf samples.

The fluorescence peak at around $\mathrm{Ex} / \mathrm{Em}=335-365 \mathrm{~nm} / 435-480 \mathrm{~nm}$ indicates the organic substances and fluorescence peak at around $E x / E m=275-290 / 310$ $335 \mathrm{~nm}$ indicates the sulfur enriched organic matter. Industry-derived organic matter in surface water had a maximum at $\mathrm{Ex} / \mathrm{Em}=350-360 / 440-450 \mathrm{~nm}$, with smaller peaks at $\mathrm{Ex} / \mathrm{Em}=360 / 465 \mathrm{~nm}$ and $385 / 480 \mathrm{~nm}$. The major peaks of the samples in this study are found at $\mathrm{Ex} / \mathrm{Em}=350-365 \mathrm{~nm} / 440-465 \mathrm{~nm}$ with 
shoulder peaks at $E x / E m=360 \mathrm{~nm} / 465 \mathrm{~nm}$ and $355-365 \mathrm{~nm} / 460-480 \mathrm{~nm}$, respectively. These fluorescence EEMs are typical for organic substances [16, 17].

The EEMs for majority of the samples (surface water, soil and blackish materials of the vegetative tissues) show the peak at $\mathrm{Ex} / \mathrm{Em}=340-350 / 440-465$ $\mathrm{nm}$ that indicates the presence of chromophoric organic matter derived from soil or industrial residues.

\subsection{Lead Concentration: Impact of Unplanned Industrialization}

Presence of different metals in the water, soil and vegetative tissues of the study area were identified by semi-quantitative analysis. $\mathrm{Hg}, \mathrm{As}, \mathrm{Cd}$ as well as $\mathrm{SO}_{4}{ }^{2-}, \mathrm{Cl}^{-}$and $\mathrm{NO}_{3}{ }^{2-}$ were present in all the water, soil and vegetative tissue samples. In addition presence and quantitative analysis of $\mathrm{Pb}$ was performed with special attention because of the presence of some battery recycling industries in the study area. The concentrations of $\mathrm{Pb}$ in water were $0.80 \mathrm{mg} / \mathrm{L}$ in summer and $1.23 \mathrm{mg} / \mathrm{L}$ in winter. On the other hand, lead contents of the soil were 1171.7 $\mathrm{mg} / \mathrm{kg}$ in summer and $2157.1 \mathrm{mg} / \mathrm{kg}$ in winter. Vegetative tissues samples contained $6585.6 \mathrm{mg} / \mathrm{kg}$ in summer and $1974.1 \mathrm{mg} / \mathrm{kg}$ of lead in winter (Figure $3)$.

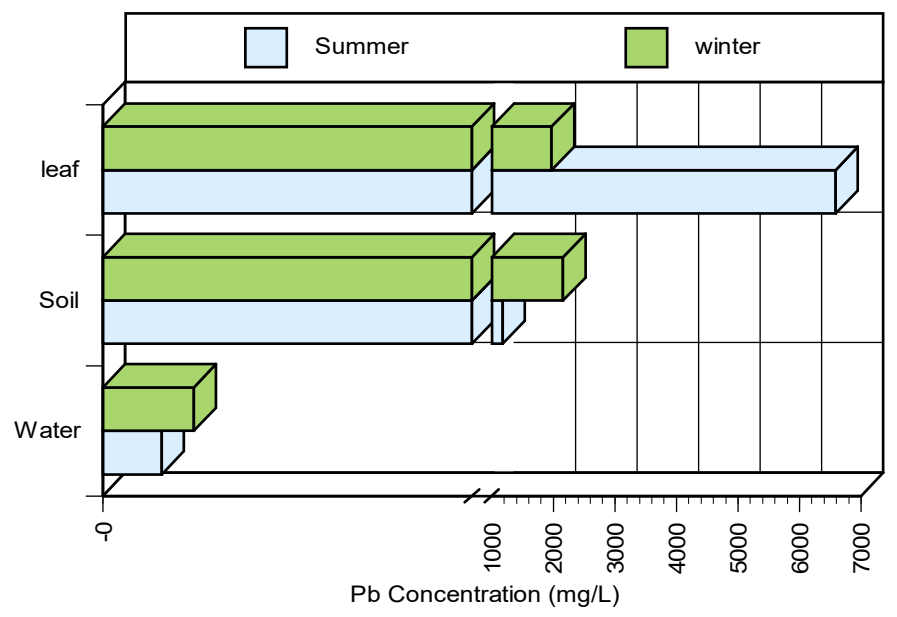

Figure 3: Lead $(\mathrm{Pb})$ concentration at different environmental compartments of the study area.

This huge amount of $\mathrm{Pb}$ is a great threat to the environment and also posses potential risk to human being. However, the concentration of lead in both soil and vegetative tissues samples varied with time and season due to wash out some part by local precipitation. Samples of this study area have exceptionally high 
lead than the average values of Dhaka city soil as well as other mega cities of the world $(20 \mathrm{mg} / \mathrm{kg})$ [18]. The blackish materials of the leaf samples and vegetative tissues have also high lead concentrations $(6500 \mathrm{mg} / \mathrm{kg})$. These high concentrations of lead might be deposited from the atmosphere due to emission of some lead enriched chemicals from some point sources. Surface deposit from air pollution $[19,20]$ and anthropogenic activities such as agriculture, industry and urban life increase the $\mathrm{Pb}$ content of soils and waters that have effects on the metal contents of vegetables [21]. One of such possible source is the nearby battery recycling industries. Continuous accumulation of this poisonous lead in different compartments of environment possesses a great threat to the urban public health.

\section{Conclusion}

Physicochemical analysis of surface water and soil as well as semiquantitative chemical analysis of the surface water, soil and blackish materials of the vegetative tissues indicated high pollution load and the presence of harmful chemical species in the study area. The presence of these harmful chemical species, industry-derived organic matter and extremely high lead concentration in soil and vegetative tissues suggested that the area is enduring excessive pollution of the different industries especially by the adjacent battery recycling industries that make it a $\mathrm{Pb}$ pollution hotspot. It is urgent to take necessary provisions and mitigation strategies to safeguard the environment and human being from the toxic impacts of lead pollution of the study area.

AcknowledgementsAuthors would like thank to the Department of Environmental Sciences and Wazed Miah Science Research Centre (WMSRC) Jahangirnagar University for full technical and instrumental support for all kinds of physical and chemical analyses.

\section{References}

[1] Chowdhury M.S. and Deb P. (2012) Urban Local Government and Environmental Management in Bangladesh: A Study on ChunarughatPaurashava. Bangladesh Development Research Center (BDRC).

[2] MoEF (Ministry of Environment and Forest). (2013) Bangladesh initiatives towards 3R approaches: A Country Analysis Paper.Government of People's Republic of Bangladesh.

[3] Rahman S.H., Khanam D., Adyel T.M., Islam M.S., Ahsan M.A. and Akbor M.A. (2012) Assessment of Heavy Metal Contamination of Agricultural Soil around Dhaka Export Processing Zone (DEPZ), Bangladesh:Implication of Seasonal Variation and Indices. Applied Sciences, 2, 584-601. 
[4] Mortula M.M., Rahman M.S. (2002) Study on waste disposal at DEPZ.Bangladesh Environment (BAPA), 2, 807-817.

[5] Ahmed G., Uddin M.K., Khan G.M., Rahman M.S., Chowdhury D.A. (2009) Distribution of trace metal pollutants in surface water system connected to effluent disposal points of Dhaka Export Processing Zone (DEPZ), Bangladesh: A statistical approach. Journal of Nature Science \& Sustainable Technology, 3, 293-304.

[6] Reddi K.R., Jayaraju N., Suriyakumar I. and Sreenivas K. (1993) Tidal flunctuation in relation to certain physico-chemical parameters in Swarnamukkhi river estuary, East Coast of India. Indian Journal of Marine Sciences, 22, 223-234.

[7] APHA (American Public Health Association). (1992) Standard Methods for Examination of Water and Wastewater. $18^{\text {th }}$ ed. Washington D. C., pp. 15-36, 1992.

[8] ECA (The Environmental Conservation Act). (1995) Government of People's Republic of Bangladesh.The Ministry of Environment and Forest, 1995.

[9] ECR (The Environmental Conservation Rules). (1997) Government of People's Republic of Bangladesh.The Ministry of Environment and Forest, 1997.

[10] APHA (American Public Health Association). (2005) Standard Methods for Examination of Water and Wastewater. $21^{\text {st }} \mathrm{ed}$. Washington D. C., pp. 31-39.

[11] WHO (World Health Organization). (1984)Guidelines for the Examination of Drinking Water. World Health Organization, Europe Regional Office, Copenhagen, pp 5-39

[12] Rajasegar M. (2003) Physico-chemical characteristics of the Vellar estuary in relation to shrimp farming. Journal of Environmental Biology, 24, 95-101.

[13] Waghmare N.V., Shinde V.D., Surve P.R. and Ambore N.E. (2012) Seasonal variations of phsycio-chemical characteristics of Jamgavan dam water of Hingoli District (M.S.) India. International Multidisciplinary Research Journal, 2(5), 23-25.

[14] Sawyer C.N., McCarty P.L. and Parkin G.F. (2003)Chemistry for Environmental Engineering and Science. 5th ed, New York, McGraw-Hill.

[15] BARC (Bangladesh Agricultural Research Council). (2005) Fertilizers recommendation guide- 2005. Peoples Press and Publications, Dhaka, Bangladesh.

[16] Baker A. and Curry M. (2004) Fluorescence of leachates from three contrasting landfills. Water Research, 38, 2605-2613.

[17] Chen W., Westerhoff P., Leenheer J.A., Booksh K. (2003) Fluorescence excitation-emission matrix regional integration to quantify spectra for dissolved organic matter. Environmental Science \& Technology, 37(24), 5701-5710.

[18] Singh B.R. and Steinnes E. In R. Lal and B. Stewart (eds),(1994) Soil Processes and Water Quality, Lewis Publishers, Chelsea, 233-271.

[19] Buchaver M.J. (1973) Contamination of soil and vegetation near zinc smelter by zinc, cadmium, copper and lead. Environmental Science \& Technology, 7, 131-135.

[20] Haghiri F. (1973) Cadmium uptake by plants. Journal of Environmental Quality, 2, 93-96.

[21] Alegria A., Barberfi R., Boluda R., Errecalde F., Farr R. and Lagarda M.J. (1991) Environmental cadmium, lead and nickel contamination: possible relationship between soil and vegetable content. Fresenius' Journal of Analytical Chemistry, 339, 654-657. 
